\title{
OBSERVATIONS ON THE PHYSIOLOGY AND BIOCHEMISTRY OF QUANTITATIVE BURNS
}

\author{
By IVILliaM W. L. GLENN, ${ }^{1}$ JYTTE MUUS, aNd CECIL K. DRINKER \\ (From the Department of Physiology, Hariard School of Public Health, Boston, and the \\ Dcpartment of Physiology, Mount Holyoke College, South Hadley, Massachusetts)
}

(Received for publication April 2, 1943)

Early in 1941, two of the authors began a series of experiments upon burns, being convinced that the technique of lymph collection familiar to them might permit profitable examinations of the amount and characteristics of the exudate from burned tissue. This conception depends upon the fact that tissue fluid, wherever it has been collected, and lymph are identical in composition (Drinker and Yoffey (1)).

Glenn. Peterson, and Drinker (2) published a first paper describing a readily repeatable experimental burn made by immersing the paw of an anesthetized $d o g$ in very hot water. Many experiments have been carried out on dogs, particularly those concerned with the development of new methods of treatment. But for experiments requiring large amounts of lymph in order to carry through extensive biochemical work, larger animals were needed and calves have proved very satisfactory.

Several recent reviews give a summary of the chemical changes which have been found to occur in blood from patients and experimental animals suffering from burns (3). There is general agreement that one finds an increase in non-protein nitrogen, urea. and creatinine, and a decrease in total protein and carbon dioxide combining capacity. The changes in some of the electrolytes seem to be a little less consistent, though in general there is an increase in potassium, and a decrease in sodium and chloride. The often repeated claim that there is an increase in "polypeptide nitrogen" does not seem to be supported by any clear-cut evidence.

In the present investigation, it was hoped to distinguish between what might be termed primary and secondary effects of the burn. That is to say, we attempted to determine whether any of the compounds which eventually accumulated in the blood came directly from the burned area,

${ }^{1}$ First Lieutenant, M. C., A. U. S. or whether they were released through damage to some other tissues. We assumed that lymph coming from the burned area would contain a higher concentration of substances resulting from tissue damage due to the burn than would lymph from another part of the body, or serum taken from the general circulation. On the other hand, substances of small molecular size which accumulate in the serum owing to impaired function of any of the organs would be present in the same concentration in the serum and in the lymph collected from different parts of the animal.

\section{Lymphatic cannulation in the calf}

Baum (4) wrote a copiously illustrated monograph on the lymphatics of calves and adult cattle. His plates, though numerous, do not prove very helpful in finding the vessels one wishes to cannulate in order to obtain lymph from burned legs. It was necessary to make subcutaneous injections of $\mathrm{T}-1824$ in order to fill the lymphatics, and eventually cannulation of the lymphatic, indicated in Figure $1(B)$ was found to give most of the lymph from the foreleg.

The important landmark to be sought in locating the foreleg lymphatic is the large superficial cervical lymph node ( $A$, Figure 1$)$. This node receives afferents not only from the skin and deep tissues of the foreleg, but also from the skin of the neck and upper part of the thorax. These are, however. but incidental suppliers of lymph compared to what comes from the foreleg. Furthermore, they are not reached by the hot water applied to the leg, and probably remain a constant but small factor in the lymph collected after burning. It is characteristic of lymph nodes all over the body that while many afferent vessels enter them through the capsule, the efferent flow is concentrated in a single vessel which leaves the hilus of the node and is generally large. This is the case in the calf, and by placing a cannula in 


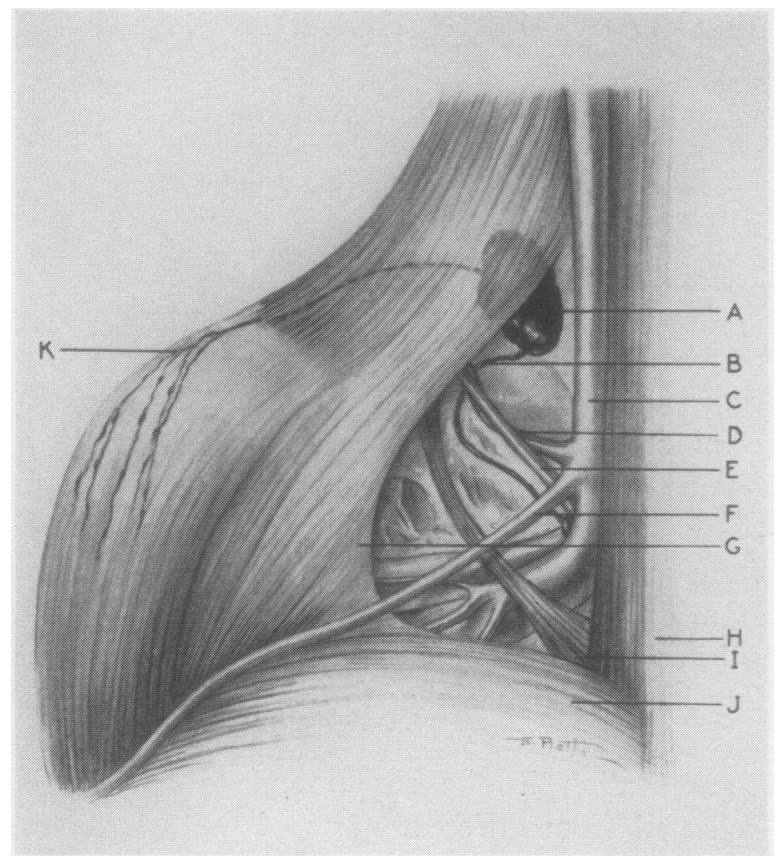

Fig. 1. Semidiagrammatic Drawing of the Lymphatic Used in Collecting Lymph from the Foreleg OF A CALF

In orienting the drawing, the head of the calf is toward the top of the drawing.

$A$, superficial cervical lymph node. $B$, efferent lymphatic running either directly into the common jugular vein or into the right lymphatic duct. This is the vessel cannulated to collect lymph. $C$, external jugular vein. $D$, inferior cervical vein. $E$, inferior cervical artery. $F$, cephalic vein. $G$, mastoido-humeralis muscle retracted to show lymph node. $H$, sterno-cephalicus muscle. $I$, relatively constant slip of the mastoido-humeralis muscle, a valuable landmark when present. $J$, superficial pectoral muscle. $K$, afferent lymphatics draining foreleg.

the efferent lymphatic ( $B$, Figure 1 ), one obtains the large amounts of lymph required for analyses before and after burning.

\section{Mcasures to promote lymph flow from burned tissues and the technique of quantita- tive burning, employing hot w'ater}

It is generally believed that lymphatics and blood vessels in a swollen part are compressed and cease to conduct fluid. Nothing could be further from the truth. In both cases, but especially in that of the lymphatics, the vessels are attached by fine bands of connective tissue to surrounding structures, and swelling results in dilatation rather than constriction. Pullinger and
Florey (5) showed this particularly well for the lymphatics in local edema.

In calves, the legs even if burned severely do not swell as dramatically as in the case of the dog. The skin is tougher and more tightly applied to the underlying muscles. In order, therefore, to obtain a copious and continuous flow of lymph, the anesthetized calf is arranged as is shown in Figure 2. This results in a steady flexion and extension of the forelegs as the $1 / 2-$ horsepower motor $(A)$, operating through reducing gears, rotates the crank $(B) 14$ times a minute. The crank is connected with the forehoofs by means of two sash cords $(C)$ readily seen in the illustration. This constant uniform motion results in a large lymph flow, which falls off only as coagulation occurs widely through the burned region and extends into the lymphatics. The problem of producing a burn by means of hot water in a calf weighing in the neighborhood of 200 pounds is not entirely simple, especially when it is recollected that the application of the water should be to a precise level upon the leg of the animal, that the duration of the exposure be regulated accurately, and that the temperature of the water be held reasonably constant. We have accomplished these requirements quite satisfactorily by making use of a piece of 8 -inch galvanized iron pipe, over the lower end of which a heavy spongerubber diaphragm reënforced by a thick sheet of solid rubber has been tied securely. This diaphragm is of the type used in an infant-size respirator and has a 2-inch hole in the center. With the animal upon his back, as shown in Figure 2, a front or hind hoof is thrust through the hole in the diaphragm and the galvanized container pushed centrally until the diaphragm has reached the selected upper limit of the prospective leg burn and a water-tight seal around the leg is obtained. The leg of the animal and the enclosing can are then securely suspended in a vertical position. Water heated to the required temperature is poured rapidly into the can and remains in contact with the leg as long as is desired. At the close of exposure, a large side vent just above the rubber diaphragm permits rapid emptying of the water.

In the present experiments, boiling water was used and it was left in contact with the leg for 


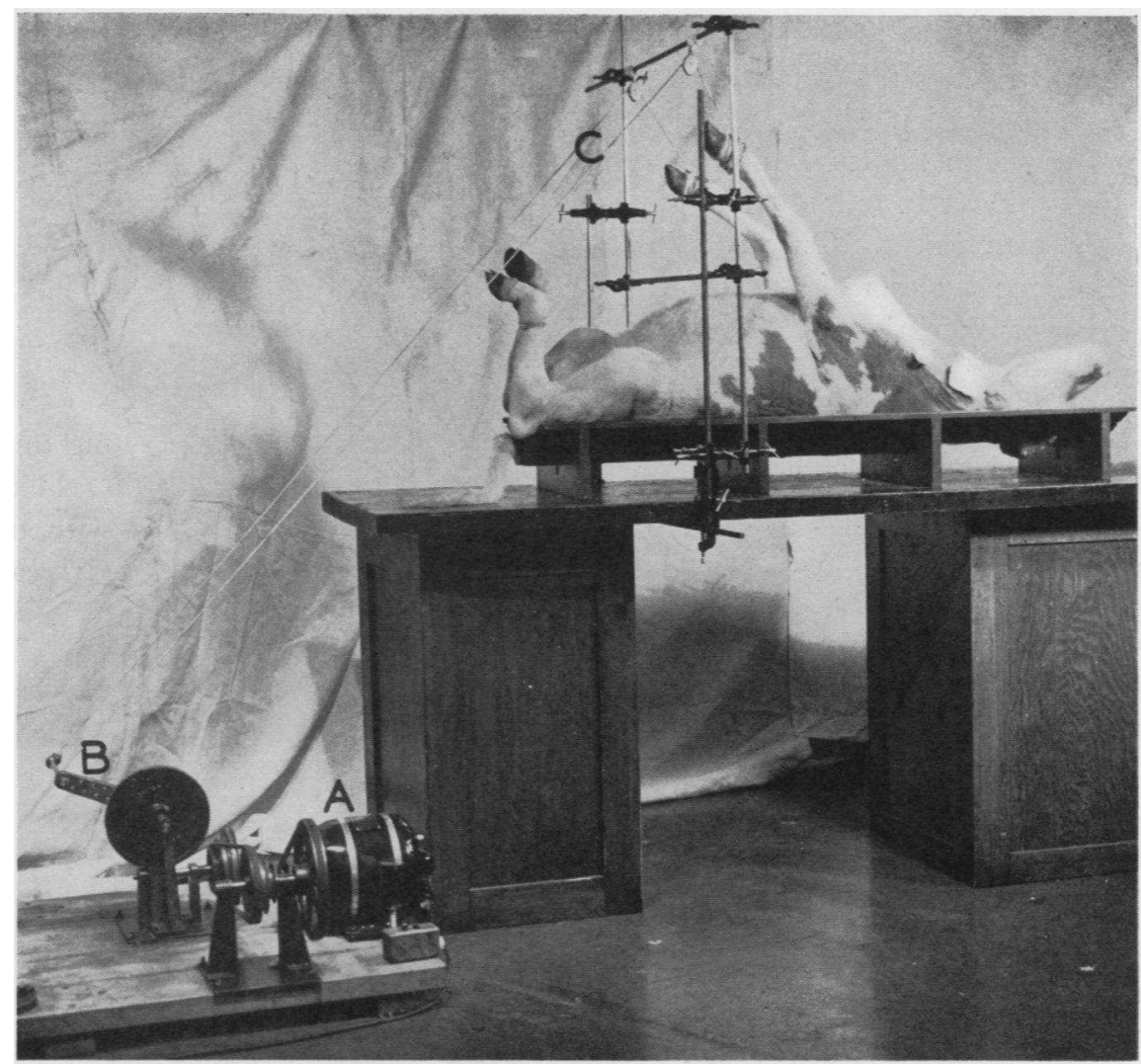

Fig. 2. Calf Anesthetized with Nembutal

Lower gauze pad is over the cannulated left foreleg lymphatic. Upper gauze pad covers the carotid artery cannulated for taking blood pressure and samples of arterial blood. The lymphatic for the right foreleg has been cannulated on the opposite side. The $1 / 2$-horsepower motor, $A$, through reducing gears, rotates the arm, $B, 14$ times a minute. Through the cords, $C$, fastened to the hoofs, this rotation results in rhythmic flexion and extension of the forelegs, and, through this passive motion, steady flow of lymph.

from $1 \frac{1}{2}$ to 4 minutes, the actual time in each experiment being recorded.

Lymph for analysis was collected simultaneously from both front legs by cannulation of the efferent lymphatic of the superficial cervical node for 2 to 3 hours before the animal was burned; then one leg was burned and collection was continued, keeping the lymph from the two legs separate and changing receivers at stated intervals, so that a series of samples representing different time intervals after the burn was at hand. One, and in some cases two, more extremities were burned after varying lengths of time.

Blood was taken before the burn, once or twice during the experiment, and at the end. The samples were usually drawn from the jugular vein, except when the animal died before the termination of the experiment, in which case the final blood was taken from the heart.

The calves used have weighed from 125 to 200 pounds, and were weaned some time previously. Calves still upon milk or just weaned arrive at the slaughter house in very variable states of hydration and nutrition. Older animals are in much more stable condition, but even so are given 10 cc. of Ringer's solution per pound of weight, intraperitoneally or intravenously, so that they may have a ready supply of fluid to draw upon. It has been our practice to anesthetize these animals at the slaughter house, using 2.5 per cent nembutal in the amount of $1 \mathrm{cc}$. for 4 pounds of body weight. This is given intravenously and very 
slowly, stopping the injection from time to time and often finishing short of the full dose, depending upon the condition, particularly the respiration of the animal. Even with this small dose, about half that used for dogs, we have lost two animals at the outset of the experiment. Once anesthesia is well established, the chances of disaster from the anesthetic are very much less.

\section{Chemical methods}

The study was confined to some. of the nitrogenous compounds always present in normal blood.

Total protein was usually determined with the Zeiss Eintauch-Refraktometer (Pulfrich), and the values were frequently checked by micro-Kjeldahl. In the microKjeldahl, the ammonia was steam-distilled and titrated in 2 per cent boric acid with methyl red as indicator. The method is a modification of Wagner's (6). The digestion was done either by the method of Wong ( 7 ) or by a slight modification of the method of Schwoegler, Babler, and Hurd (8).

The same micro-Kjeldahl procedure was used to determine the non-protein nitrogen in the tungstic acid filtrate from serum or lymph prepared according to Haden's modification of the Folin-Wu method ( 7$)$. Creatinine and creatine + creatinine were done on the tungstic acid filtrate according to Folin (9). Amino-nitrogen was determined by the gasometric method of Van Slyke (7) on whole serum and lymph and on the tungstic acid filtrate. Urea was determined on whole serum and lymph by the gasometric method of Van Slyke ( 7 ).

Oxygen content and oxygen combining capacity were determined according to Van Slyke (7).

\section{The flow and protein content of lymph from the normal and burned leg of the calf}

We have been unable to find data upon the flow and composition of lymph even from the thoracic duct of cattle. Our experience with 16 calves thus supplies information upon normal conditions as well as the contrast which occurs following a severe burn. Table $I$ is a summary of fundamental data upon 4 animals. In all cases, the lymph flow from the burned leg increased markedly immediately after the burn, and at the same time, there was an increase in the total protein of from 35 to 75 per cent of the original values. The steady decrease in the rate of lymph flow during the course of the experiment is not accompanied by a decrease in protein content, which stays very constant at the high level established right after the burn. A detailed study on the distribution of the different proteins in the lymph and serum is reported elsewhere (10).

As in the case of dogs, with which we have had prolonged experience, there is no correlation between the amount of lymph flowing from a cannulated vessel and the weight of the animal. Notice also that the largest percentile increases in lymph production as a result of burning occur when the normal flow of lymph is comparatively small. In all of these animals, the uniform passive motion described in a previous section was

TABLE I

The lymph flow and protein content from the normal and burned forelegs of 4 calves, por hour for consecutive hours immediately before and after burn

\begin{tabular}{|c|c|c|c|c|c|c|c|c|c|c|}
\hline \multirow{3}{*}{$\begin{array}{c}\text { Number } \\
\text { of } \\
\text { calf }\end{array}$} & \multirow{3}{*}{ Weight } & \multirow{3}{*}{$\begin{array}{l}\text { Control } \\
\text { blood } \\
\text { protein }\end{array}$} & \multicolumn{4}{|c|}{ Forelegs prior to burning } & \multicolumn{4}{|c|}{ Forelegs following burning* } \\
\hline & & & \multicolumn{2}{|c|}{ Lymph flow } & \multicolumn{2}{|c|}{ Lymph protein } & \multicolumn{2}{|c|}{ Lymph flow } & \multicolumn{2}{|c|}{ Lymph protein } \\
\hline & & & $\mathrm{R}$ & $\mathrm{L}$ & $\mathrm{R}$ & $\mathrm{L}$ & $\mathrm{R}$ & $\mathrm{L}$ & $\mathrm{R}$ & $\mathrm{L}$ \\
\hline & lbs. & per cent & \multicolumn{2}{|c|}{ cc. per hr. } & \multicolumn{2}{|c|}{ per cent } & \multicolumn{2}{|c|}{ cc. per hr. } & \multicolumn{2}{|c|}{ per cent } \\
\hline 2 & 200 & 6.0 & $\begin{array}{l}7.4 \\
7.3\end{array}$ & $\begin{array}{l}4.7 \\
4.2\end{array}$ & 2.8 & 2.2 & $\begin{array}{r}12.9 \\
8.0\end{array}$ & $\begin{array}{l}48.3 \\
41.0\end{array}$ & 3.1 & 3.7 \\
\hline 6 & 165 & 5.4 & $\begin{array}{l}7.0 \\
6.5\end{array}$ & $\begin{array}{l}9.0 \\
6.0\end{array}$ & 2.5 & 2.6 & $\begin{array}{l}25.5 \\
28.0\end{array}$ & $\begin{array}{l}9.2 \\
6.0\end{array}$ & 4.4 & 2.6 \\
\hline 8 & 155 & 6.7 & $\begin{array}{l}20.0 \\
21.0\end{array}$ & $\begin{array}{l}23.0 \\
22.0\end{array}$ & 3.1 & 3.1 & $\begin{array}{r}12.0 \\
10.0 \\
8.5\end{array}$ & $\begin{array}{l}36.0 \\
15.0 \\
19.0\end{array}$ & 3.1 & 4.3 \\
\hline 9 & 190 & 6.3 & $\begin{array}{l}21.5 \\
18.0 \\
14.5\end{array}$ & $\begin{array}{l}22.0 \\
19.0 \\
11.0\end{array}$ & 2.9 & 2.9 & $\begin{array}{l}23.0 \\
33.0 \\
27.0\end{array}$ & $\begin{array}{l}17.0 \\
19.0 \\
11.0\end{array}$ & 3.8 & 2.7 \\
\hline
\end{tabular}

* Burned forelegs in italics. 


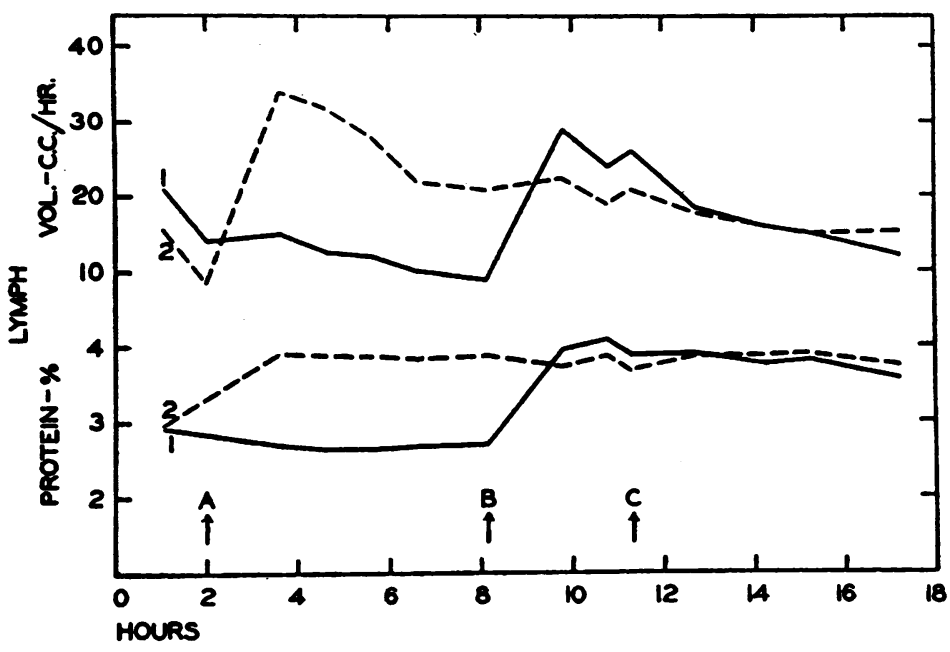

Fig. 3. Curves Showing the Rate of Flow and Protein Content of Lymph from the Normal and Burned Forelegs of a Calf Weighing 170 Pounds

Ordinates, protein in per cent and lymph flow per hour in cubic centimeters. Curve 1 (solid line, upper), cubic centimeters of lymph per hour from right foreleg. From 0 to arrow $B$, normal period. At arrow $B$, immersed 3 minutes in water at $100^{\circ} \mathrm{C}$. Curve 1 (solid line, lower), protein concentration in per cent of right foreleg lymph. Curve 2 (broken line, upper), cubic centimeters of lymph per hour from left foreleg. From 0 to arrow $A$, normal period. At arrow $A$, immersed 3 minutes in water at $100^{\circ} \mathrm{C}$. Curve 2 (broken line, lower), protein concentration in per cent of left foreleg lymph. At arrow $C$, the left hind leg was immersed in water at $100^{\circ} \mathrm{C}$. for 3 minutes.

in operation during the period of normal collection and after burning. Lacking this mild cause of lymph movement, no lymph would be secured during the control period, and though a substantial flow would follow burning, it would be much less than that accompanying constant passive motion.

Figure 3 presents a continuous record of lymph flow and lymph protein from a calf weighing 170 pounds and severely burned. At arrow $A$, the left foreleg was immersed in water at $100^{\circ} \mathrm{C}$. for 3 minutes. The effects on lymph flow and lymph protein content are shown in the broken lines, 2 and 2. At arrow $B$, the right foreleg was burned similarly, with the results shown in the solid lines, 1 and 1 . At arrow $C$, the left hind leg was burned in order to see whether a simple extension of the lesion in an area remote from those in which lymph was being collected would indirectly influence lymph formation. This final burn had no recognizable effect, nor have we ever been successful in enhancing lymph flow from an unburned region by even extremely severe burns in distant regions.

The normal mean arterial pressure in the carotid artery of the calf, anesthetized with nembutal, varies between 160 and $180 \mathrm{~mm}$. $\mathrm{Hg}$. In the experiment shown in Figure 3, it was $162 \mathrm{~mm}$. $\mathrm{Hg}$ prior to burning, $182 \mathrm{~mm}$. $\mathrm{Hg} 1$ hour after the first burn (arrow A), $204 \mathrm{~mm}$. $\mathrm{Hg} 5$ hours after the first burn, and $156 \mathrm{~mm} . \mathrm{Hg} 14$ hours after the first burn and near the end of the experiment. No attempts were made to measure venous pressures before and after burning, but Field, Drinker, and White (11), in severe burns of the $\mathrm{dog}$, found that venous pressures taken from large vessels immediately above the level of the burn rose rapidly following burning.

\section{Chemical changes}

Complete data from two experiments are given in Tables II and III. Table IV gives a summary of the maximal changes observed in each experiment. 


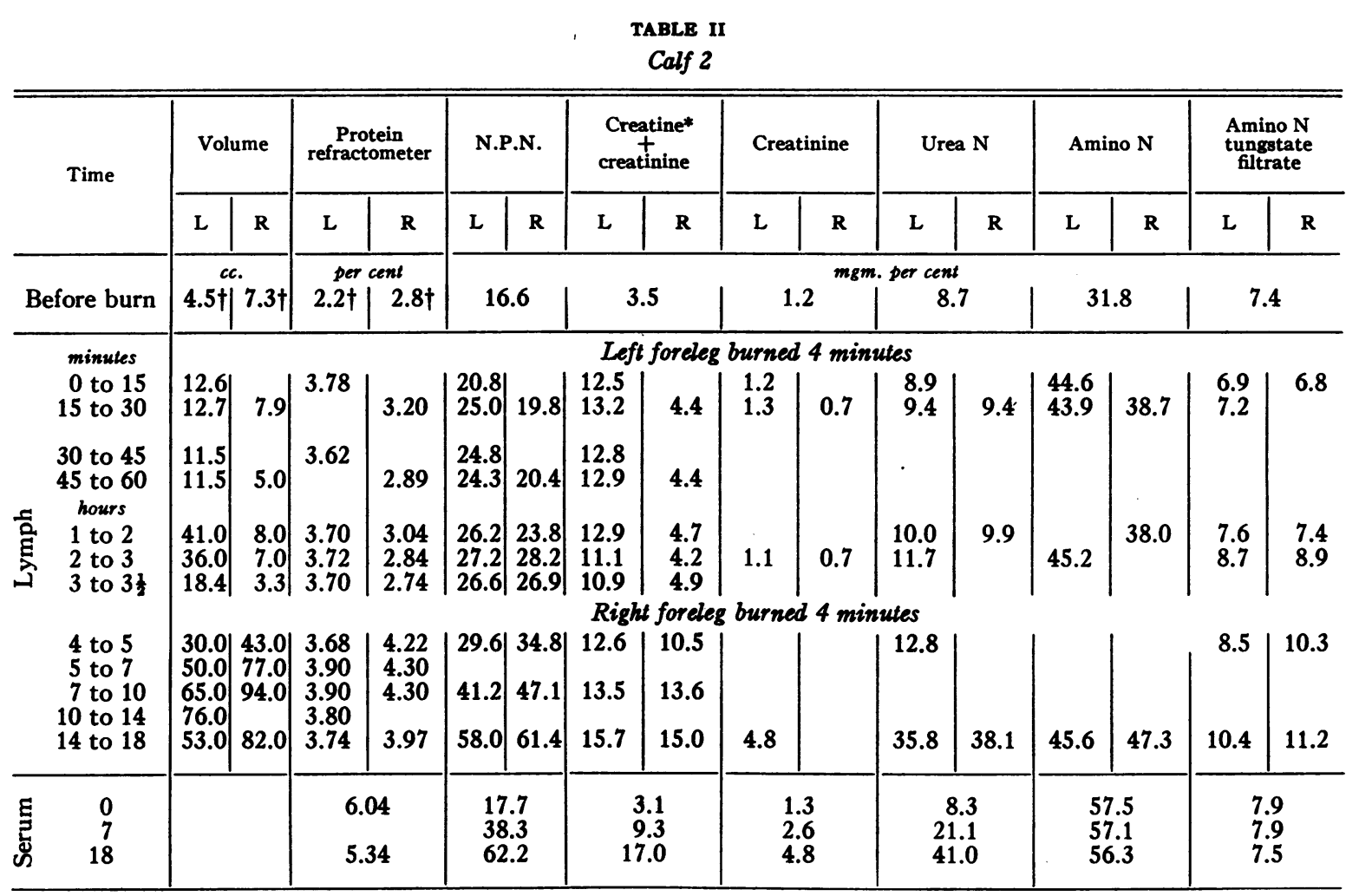

* Creatine + creatinine given as creatinine.

The non-protein nitrogen increased in all experiments. This increase occurred at about the same rate in lymph from both the burned and unburned leg and in the serum. The values for "end serum" are usually somewhat higher than those for the last lymph samples. This is to be expected when there is a continuous rise in nonprotein nitrogen, since the last lymph sample contains all the lymph taken during the last 2 to 4 hours while the "end serum" is taken at the time the experiment was terminated.

The case of creatine and creatinine is not quite as clear. In most cases, a slow increase which occurs at about the same rate in both legs is observed. In the case of calf 2 , as shown in Table II, there is an immediate increase in creatine from the burned leg, and this level is maintained with only a small further increase toward the end of the experiment. Calf 3, which survived for only 4 hours, showed a similar picture.

The results of the amino- $\mathrm{N}$ determinations are irregular. In some cases, the amount in the lymph from the burned leg was higher than in the unburned; in other cases, the opposite was true.
These differences were not large enough to be significant. Surprising, however, is the difference between the concentration in lymph and serum at the end of the experiments (Table IV). Calves $2,5,6$, and 7 have a higher concentration of amino- $\mathrm{N}$ in the lymph than in the serum. The lymph samples for calves 4 and 9 were taken some hours before the serum sample, leaving only calf 3 with a much higher concentration of the amino-N in the serum than in the lymph. As already mentioned, calf 3 died after only 4 hours; it should also be pointed out in this connection that there was considerable hemoglobinemia, there being a concentration of 2.3 per cent hemoglobin in the serum.

A control experiment was carried out to determine how much effect the nembutal anesthesia in itself would have on the different blood and lymph constituents. Very small changes only were observed. None of the changes encountered in the burned animals can be explained as a result of the anesthesia.

Our original assumption was that compounds set free by tissue damage in the burned area would 
be present in the lymph from this area in higher concentration than in the lymph from an unburned area or in the serum from the general circulation. If this is correct, then our results indicate that the increase in the compounds studied, with the possible exception of creatine, is due to metabolic changes elsewhere in the body.

It is generally assumed that urea is formed in the liver and not in other tissues and there would, therefore, be no reason to expect any formation of urea in the burned area. The increase in urea and creatinine could both be explained as an accompaniment of the oliguria which regularly occurs after severe burns. The very high nitrogen output reported for patients with burns (12) indicates increased protein catabolism, and the increase in urea might be due to a combination of increased formation and decreased excretion.

The relative increase in creatinine is about the same as the relative increase in total non-protein nitrogen. On the other hand, the increase in creatine is both relatively and absolutely greater than the increase in creatinine. It does not seem likely that this can be explained as a result of oliguria. Creatine is not normally excreted in the urine, but Chanutin and Silvette (13) found, in spite of this, that nephrectomy caused an increase in the creatine as well as in the creatinine of the blood, though the increase in creatine was less than that in creatinine. This result resembles the usual findings in nephritis and Miller and Dubos (14) have shown that in cases of nephritis as much as 30 per cent of the color produced in the Jaffe reaction may be due to compounds other than creatinine. We performed a few tests using Miller and Dubos's specific bacterial enzyme to prove the identity of the creatine and creatinine. The "end serum" from calf 9 was used. All the

TABLE III

Calf 9

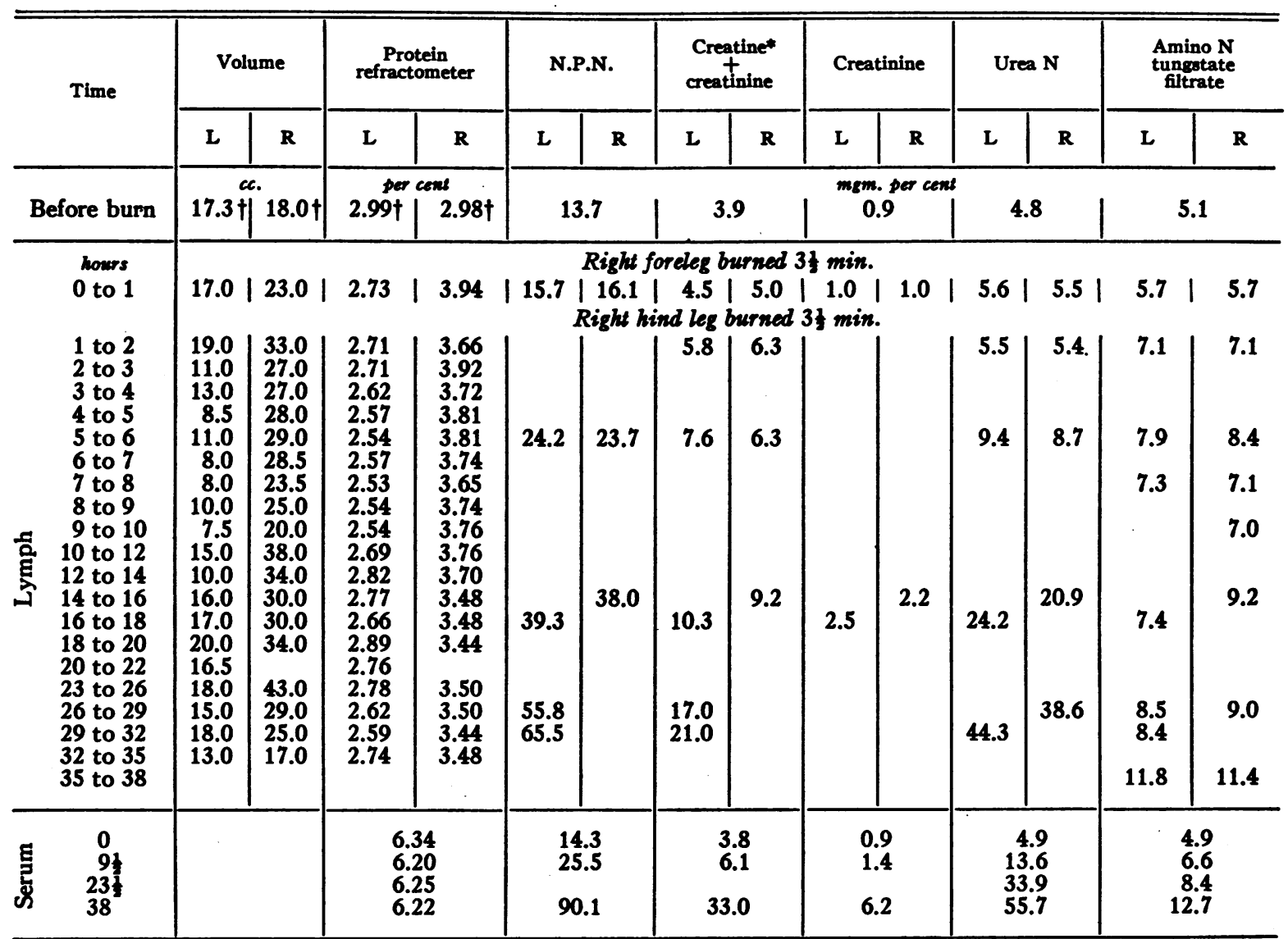

- Creatine + creatinine given as creatinine.

† Average per hour. 
TABLE IV

\section{Summary of analytical data}

Normal serum and lymph were taken before burn, end serum was taken at the termination of the experiment, and end lymph was collected from the burned leg during a 3 to 4 -hour period just prior to the termination of the experiment except in the cases where actual time is given in footnote

\begin{tabular}{|c|c|c|c|c|c|c|c|c|c|c|c|c|c|c|}
\hline \multirow{2}{*}{$\underset{\text { num- }}{\text { Calf }}$} & \multirow{2}{*}{$\begin{array}{l}\text { Time } \\
\text { after } \\
\text { initial } \\
\text { burn }\end{array}$} & \multicolumn{2}{|l|}{ Protein } & \multicolumn{2}{|c|}{ N.P.N. } & \multicolumn{2}{|c|}{ Creatinine } & \multicolumn{2}{|c|}{$\begin{array}{c}\text { Creatine } \\
+ \\
\text { creatinine }\end{array}$} & \multicolumn{2}{|c|}{ Urea $\mathbf{N}$} & \multicolumn{2}{|c|}{$\begin{array}{c}\text { Amino } N \text { in } \\
\text { tungstate } \\
\text { filtrate }\end{array}$} & \multirow{2}{*}{ Remarks } \\
\hline & & Normal & End & Normal & End & Normal & End & Normal & End & Normal & End & Normal & End & \\
\hline & hours & per cent & & & & & & $m g m$. & per cent & & & & & \\
\hline 1 & $15 \frac{1}{2}$ & $\begin{array}{ll}\text { Lymph } & 2.42 \\
\text { Serum } & 5.39\end{array}$ & $\begin{array}{l}3.91 \\
6.04\end{array}$ & $\begin{array}{l}16.7 \\
16.7\end{array}$ & $\begin{array}{l}73.5 \\
84.8\end{array}$ & $\begin{array}{l}1.0 \\
1.1\end{array}$ & $\begin{array}{l}4.5 \\
4.9\end{array}$ & $\begin{array}{l}3.2 \\
2.9\end{array}$ & $\begin{array}{l}22.5 \\
25.5\end{array}$ & & & & & $\begin{array}{l}\text { Burned left foreleg } \\
2 \frac{1}{2} \text { minutes; } 3 \text { hours } \\
\text { later, right foreleg } \\
2 \text { minutes }\end{array}$ \\
\hline 2 & 18 & $\begin{array}{l}\text { Lymph } 2.20 \\
\text { Serum } 6.04\end{array}$ & $\begin{array}{l}3.74 \\
5.34\end{array}$ & $\begin{array}{l}16.6 \\
17.7\end{array}$ & $\begin{array}{l}58.0 \\
62.2\end{array}$ & $\begin{array}{l}1.2 \\
1.3\end{array}$ & $\begin{array}{l}4.8 \\
4.8\end{array}$ & $\begin{array}{l}3.5 \\
3.1\end{array}$ & $\begin{array}{l}15.7 \\
17.0\end{array}$ & $\begin{array}{l}8.7 \\
8.3\end{array}$ & $\begin{array}{l}36.8 \\
41.0\end{array}$ & $\begin{array}{l}7.4 \\
7.9\end{array}$ & $\begin{array}{r}10.4 \\
7.5\end{array}$ & $\begin{array}{l}\text { Burned left foreleg } \\
4 \text { minutes; } 4 \text { hours } \\
\text { later, right foreleg } \\
4 \text { minutes }\end{array}$ \\
\hline 3 & .4 & $\begin{array}{l}\text { Lymph } 2.34 \\
\text { Serum } 6.10\end{array}$ & 3.97 & $\begin{array}{l}27.6 \\
26.0\end{array}$ & $\begin{array}{l}54.0 \\
67.8\end{array}$ & $\begin{array}{l}1.5 \\
1.3\end{array}$ & $\begin{array}{l}2.6 \\
3.9\end{array}$ & $\begin{array}{l}4.5 \\
4.1\end{array}$ & $\begin{array}{l}20.2 \\
21.6\end{array}$ & $\begin{array}{l}16.8 \\
17.2\end{array}$ & $\begin{array}{l}22.7 \\
26.0\end{array}$ & $\begin{array}{l}5.1 \\
3.7\end{array}$ & $\begin{array}{l}12.4 \\
20.4\end{array}$ & $\begin{array}{l}\text { Burned left hind leg } \\
3 \text { minutes; right } \\
\text { hind leg } 3 \text { minutes; } \\
1 \text { hour later, right } \\
\text { foreleg } 3 \text { minutes }\end{array}$ \\
\hline 4 & 11 & $\begin{array}{l}\text { Lymph } 3.34 \\
\text { Serum } 6.75\end{array}$ & \begin{tabular}{|l|}
4.36 \\
6.43 \\
\end{tabular} & $\begin{array}{l}27.5 \\
28.6\end{array}$ & $\begin{array}{l}72.3^{*} \\
96.8\end{array}$ & $\begin{array}{l}1.0 \\
1.0\end{array}$ & $\begin{array}{l}3.8 \\
5.7\end{array}$ & $\begin{array}{l}4.5 \\
4.5\end{array}$ & $\begin{array}{l}21.5 \\
27.5\end{array}$ & $\begin{array}{l}13.9 \\
13.5\end{array}$ & $\begin{array}{l}29.7 \dagger \\
45.3\end{array}$ & $\begin{array}{l}6.3 \\
6.0\end{array}$ & $\begin{array}{l}16.5 t \\
18.5\end{array}$ & $\begin{array}{l}\text { Burned left foreleg } \\
3 \text { minutes; } 1 \frac{1}{3} \text { hours } \\
\text { later, left hind leg } \\
3 \text { minutes; } 8 \text { hours } \\
\text { later, right hind leg } \\
3 \text { minutes }\end{array}$ \\
\hline 5 & 10 & $\begin{array}{l}\text { Lymph } 2.42 \\
\text { Serum } 6.38\end{array}$ & \begin{tabular}{|l|}
3.88 \\
5.34
\end{tabular} & $\begin{array}{l}19.7 \\
20.5\end{array}$ & $\begin{array}{l}38.6 \\
41.8\end{array}$ & $\begin{array}{l}1.1 \\
1.3\end{array}$ & $\begin{array}{l}2.1 \\
2.9\end{array}$ & $\begin{array}{l}4.3 \\
3.9\end{array}$ & $\begin{array}{r}9.8 \\
12.0\end{array}$ & 11.3 & 19.8 & $\begin{array}{l}5.6 \\
5.3\end{array}$ & $\begin{array}{r}11.9 \\
9.0\end{array}$ & $\begin{array}{l}\text { Burned right fore- } \\
\text { leg } 3 \text { minutes; } 5 \\
\text { hours later, left } \\
\text { hind leg } 1 \neq \text { minutes; } \\
2 \text { hours later, right } \\
\text { hind leg } 1 \frac{1}{2} \text { minutes }\end{array}$ \\
\hline 6 & 17 & $\begin{array}{l}\text { Lymph } 2.46 \\
\text { Serum } 6.30\end{array}$ & \begin{tabular}{|l|}
3.56 \\
4.76
\end{tabular} & $\begin{array}{l}18.9 \\
19.8\end{array}$ & $\begin{array}{l}41.7 \\
48.4\end{array}$ & $\begin{array}{l}1.2 \\
0.9\end{array}$ & $\begin{array}{l}2.4 \\
2.6\end{array}$ & $\begin{array}{l}4.5 \\
3.9\end{array}$ & $\begin{array}{r}9.9 \\
12.3\end{array}$ & 9.4 & 24.4 & $\begin{array}{l}6.0 \\
5.8\end{array}$ & $\begin{array}{r}12.3 \\
8.9\end{array}$ & $\begin{array}{l}\text { Burned right fore- } \\
\text { leg } 3 \frac{1}{1} \text { minutes; } 12 \\
\text { hours later, right } \\
\text { hind leg } 3 \frac{1}{2} \text { minutes }\end{array}$ \\
\hline 7 & $15 \frac{1}{2}$ & $\begin{array}{l}\text { Lymph } 2.96 \\
\text { Serum } 7.04\end{array}$ & \begin{tabular}{|l|}
3.80 \\
6.24 \\
\end{tabular} & $\begin{array}{l}21.4 \\
19.9\end{array}$ & $\begin{array}{l}37.5 \\
36.3\end{array}$ & 0.9 & 1.8 & $\begin{array}{l}4.8 \\
5.1\end{array}$ & $\begin{array}{l}8.3 \\
8.4\end{array}$ & & & $\begin{array}{l}7.3 \\
5.4\end{array}$ & $\begin{array}{l}9.7 \\
6.8\end{array}$ & $\begin{array}{l}\text { Burned left foreleg } \\
3 \text { minutes; } 6 \text { hours } \\
\text { later, right foreleg } \\
3 \text { minutes; } 2 \frac{1}{2} \text { hours } \\
\text { later, left hind leg } \\
3 \text { minutes }\end{array}$ \\
\hline 9 & 38 & $\begin{array}{l}\text { Lymph } 2.98 \\
\text { Serum } 6.34\end{array}$ & $\begin{array}{l}3.48 \\
6.22 \\
\end{array}$ & $\begin{array}{l}13.7 \\
14.3\end{array}$ & $\begin{array}{l}65.5 \ddagger \\
90.1\end{array}$ & $\begin{array}{l}0.9 \\
0.9\end{array}$ & 6.2 & $\begin{array}{l}3.9 \\
3.8\end{array}$ & $\begin{array}{l}21.0 \dagger \\
33.0\end{array}$ & $\begin{array}{l}4.8 \\
4.9\end{array}$ & $\begin{array}{l}44.3 \ddagger \\
55.7\end{array}$ & $\begin{array}{l}5.1 \\
4.9\end{array}$ & $\begin{array}{r}8.4 t \\
12.7\end{array}$ & $\begin{array}{l}\text { Burned right fore- } \\
\text { leg } 3 \frac{1}{3} \text { minutes; } 1 \\
\text { hour later, right } \\
\text { hind leg } 3 \frac{1}{2} \text { minutes }\end{array}$ \\
\hline
\end{tabular}

* Sample $6 \frac{1}{2}$ to $8 \frac{1}{2}$ hours.

† Sample $4 \frac{1}{2}$ to $6 \frac{1}{2}$ hours.

‡ Sample 29 to 32 hours.

chromogenic material, also that produced by acid hydrolysis, disappeared after incubation with the bacteria. $^{2}$ This would prove quite conclusively

2 We wish to thank Dr. René Dubos for kindly presenting us with cultures of Corynebacterium creatinovorans. that the chromogenic material was true creatine and creatinine.

The results from calf 2 show that it is possible, at least under certain conditions, to demonstrate that creatine is released in the burned area. Muscle cells are known to have a high concentration 
of creatine and an injury to such cells, to the extent of releasing material usually confined to the inside of the cells, would result in an increase of creatine in the extracellular fluids. A possible explanation for our failure to observe this phenomenon in the majority of our experiments is that the creatine (and possibly other constituents) is diffused so rapidly from the tissue fluid into the capillaries that the differences in concentrations between blood and lymph are too small to be determined.

An increase of amino acid in the blood has been found in late stages of nephritis, but this is by no means a constant finding. Kirk (15), from his observations, concludes that the occurrence of amino acid in the blood of patients with nephritis is not due directly to renal failure but to a metabolic failure elsewhere. After nephrectomy, there is very little, if any, increase in amino acid (16, 17). Our experiments give no clue to the source of the amino nitrogen, but an increase in amino acid might result either from liver damage or from increased protein catabolism.

An increase in "undetermined nitrogen" out of proportion to the increase in total non-protein nitrogen has been found in cases of burns (18). In our experiments, the "undetermined nitrogen" does not increase proportionately more than the total non-protein nitrogen except in the case of calf 3 .

\section{CONCLUSIONS}

Our studies indicate that there is no increase in capillary permeability in normal regions of the body distant from the burn. The increase in urea and creatinine is consistent with the usual findings attending oliguria. An explanation of the increase in creatine and amino nitrogen requires further studies which we are now undertaking. It is tentatively suggested that the increase in creatine is due to tissue damage in the burned area.

\section{SUMMARY}

1. A method of anesthesia and cannulation of the principal lymphatic draining the foreleg of the calf is described.

2. A method for providing steady passive motion of the legs and so inducing constant conditions of lymph flow is described and illustrated.
3. The technique of producing repeatable and reasonably quantitative burns of the leg of a calf weighing 125 to 200 pounds is described.

4. By means of a table and curves, the lymph flow and lymph protein content from normal and burned forelegs of calves are presented.

5. Non-protein nitrogen, urea, creatinine, creatine + creatinine, and amino nitrogen were determined in lymph from a burned area, in lymph from an area remote from the burn, and in serum. The results are presented in tabular form.

The authors wish to express their appreciation to Helen H. Gilbert and H. S. Amory Potter for technical assistance during experiments lasting through one and even two nights, and to Marion Blanchard and Esther Hardenbergh for aiding in chemical analyses.

\section{BIBLIOGRAPHY}

1. Drinker, C. K., and Yoffey, J. M., Lymphatics, Lymph, and Lymphoid Tissue. Harvard University Press, Cambridge, Mass., 1941, pages 58-65.

2. Glenn, W. W. L., Peterson, D. K., and Drinker, C. $\mathrm{K}$., The flow of lymph from burned tissue, with particular reference to the effects of fibrin formation upon lymph drainage and composition. Surg., 1942, 12, 685.

3. Harkins, H. N., The Treatment of Burns. Charles C. Thomas, Springfield, Ill., 1942.

Lam, C. R., The chemical pathology of burns. Surg., Gynec. and Obst., Int. Abs., 1941, 72, 390.

McClure, R. D., The treatment of the patient with severe burns. J. A. M. A., 1939, 113, 1808.

4. Baum, H., Das Lymphgefässsystem des Rindes. August Hirschwald, Berlin, 1912.

5. Pullinger, B. D., and Florey, H. W., Some observations on the structure and functions of lymphatics: their behaviour in local oedema. Brit. J. Exper. Path., 1935, 16, 49.

6. Wagner, E. C., Titration of ammonia in presence of boric acid. Indust. and Engin. Chem., Analytical Edition, 1940, 12, 771.

7. Peters, J. P., and Van Slyke, D. D., Quantitative Clinical Chemistry. Vol. II, Methods. Williams and Wilkins Co., Baltimore, 1932.

8. Schwoegler, E. J., Babler, B. J., and Hurd, L. C., Copper selenite as a catalyst in the Kjeldahl nitrogen determination. J. Biol. Chem., 1936, 113, 749.

9. Folin, O., Laboratory Manual of Biological Chemistry. D. Appleton Co., New York, 1926.

10. Perlmann, G. E., Glenn, W. W. L., and Kaufman, D., Changes in the electrophoretic pattern in lymph and serum in experimental burns. (To be published.) 11. Field, M. E., Drinker, C. K., and White, J. C., 
Lymph pressures in sterile inflammation. J. Exper. Med., 1932, 56, 363.

12. Davidson, E. C., Sodium chloride metabolism in cutaneous burns and its possible significance for a rational therapy. Arch. Surg., 1926, 13, 262.

13. Chanutin, A., and Silvette, H., A study of creatine metabolism in the nephrectomized white rat. J. Biol. Chem., 1929-1930, 85, 179.

14. Miller, B. F., and Dubos, R., Determination by a specific, enzymatic method of the creatinine content of blood and urine from normal and nephritic individuals. J. Biol. Chem., 1937, 121, 457.
15. Kirk, E., Amino nitrogen changes of the blood in nephritis. J. Clin. Invest., 1933, 12, 1091.

16. Cerqua, S., La curva aminoacidemica nell' uremia sperimentale. Minerva Med., 1933, 2, 802.

17. Bollman, J. L., Mann, F. C., and Magath, T. B., Studies on the physiology of the liver. VIII. Effect of total removal of the liver on the formation of urea. Am. J. Physiol., 1924, 69, 371.

18. Lambret, O., and Driessens, J., Le syndrome humorotissulaire des brûlures étendues. Rev. de chir., Paris, 1937, 75, 319. 